\title{
TUTKIMUSTEMME KÄRKI ON HYVÄÄ KANSAINVÄLISTÄ TASOA
}

\author{
Aikuiskasvatus-lehti asetti syksyllä 1994 arviointiryhmän, \\ jonka tehtävänä oli arvioida tuoreimman suomalaisen \\ aikuiskasvatustutkimuksen sovellettavuutta ja käyttökelpoisuutta \\ käytännön aikuiskasvatustyössä. Kaikki viisi jäsentä sitoutuivat \\ kahlaamaan läpi tyydyttävällä tarkkuudella ne tutkimukset, joita \\ yliopistojen kasvatustieteen laitokset halusivat omalta \\ osaltaan nostaa arvioitaviksi.
}

Tutkimusraporttien ja teosten valinnan suorittivat siis yliopistot. Lehti pyysi kultakin laitokselta 2-3 tutkimusta. Näin saatiin käsiteltäväksi uusimpien tutkimusten mielenkiintoisin kärki, eräässä mielessä helmet. Arvioitavaksi tuli 24 yliopistojen julkaisemaa tutkimusraporttia tai sellaista tieteellistä teosta, joiden kustantajaksi oli saatu kaupallinen kustantaja.

\section{Keitä arvioryhmään kuului?}

Arvioryhmään valittiin viisi kouluttajaa keskenään erilaisin työtaustoin. Puheenjohtajaksi kutsuttiin tohtori Arja Puurula Helsingin yliopiston Vantaan täydennyskoulutuslaitoksesta. Arja Puurula edusti aiemman työkokemuksensa Elannon osastopäällikkönä perusteella ryhmässä myös elinkeinoelämän näkökulmaa. Oppimiskonsultti Cristina Andersson CS-Develor OY:stä etsii omaan koulutuskonsultin työhönsä tutkimuksista kättä pidempää. Koulutuspäällikkö Matti Hermunen Tielaitoksesta tuli ryhmään julkishallinnosta. Mikko Takalan reviirinä on vuorostaan ammatillinen aikuiskoulutus - hän on Vantaan väliaikaisen ammattikorkeakoulun rehtori. Ahti Valken kokemuspiirinä on vapaa sivistystyö. Hän on pitkään työskennellyt Opintotoiminnan keskusliiton pedagogisena sihteerinä. jokainen arvioryhmän jäsen on samalla henkilö, joka pyrkii kehittämään omaa osaamistaan ja rikastuttamaan työtään myös tutkimustiedolla.

Kaikilla arvioryhmän jäsenillä oli omat kappaleensa tutkimuksista, joten jokaisella oli mahdollisuus säädellä lukuaikatauluaan ja lukemisen perusteellisuusastetta henkilökohtaisen tilanteensa mukaan. jokainen viidestä on työssään kiireinen ja kuormitettu, joten heidän tuli sovittaa lukemisurakkansa omaa työtään ja ammattitaitoaan edesauttavaan intressiin. Intressilähtökohdasta johtuen lukuprosessit olivat myös valikoivia ja rekonstruoivat siten aikuiskouluttajien arkista tilannetta: jokin tutkimus kahlattiin hatarammin, jotain luettiin kahteenkin kertaan. Tarkka syventyminen, joka on välttämätöntä väitöskirjan lausunnonantajan työskentelylle, ei työryhmän tehtäväksiannon valossa ollut sen enempää mahdollinen kuin tarkoituksenmukainenkaan.

Nimetyistä teoksista karsiutuivat alkuvaiheessa pois ne julkaisut ja tutkimukset, joiden painos oli loppunut, sillä yhtenä kriteerinä oli tutkimusten yleinen saatavuus. Näin mahdollisen lisäpainoksen epäonnekas ajoittuminen saattoi talvella jättää jonkin tärkeänkin tutkimuksen arviointiryhmän työskentelyn ulkopuolelle. Monisteita (joita tuli yksi) ei hyväksytty käsittelyyn. Tilastokeskuksen aikuiskoulutustutkimuksen materiaalia eri näkökulmista hyödyntäneissä turkulaistutkimuksissa tehtiin paljouskarsinta ja arviointiin valittiin kuudesta kaksi uusinta.

Arvioryhmä kokoontui neljä kertaa. Ensimmäisellä kerralla sovittiin pelisäännöt ja aikataulu. Yksimielisyys vallitsikin siitä, että tieteelliset kriteerit ovat yliopistot asettaneet itse, eikä ryhmän asiana ole tehdä tieteellistä arviointia. Itsestään selvänä pidettiin myös sitä, että tehtävänä ei ole etsiä "parasta" tutkimusta. Liioin arvioryhmä ei pyrkinyt "objektiivisuuteen". Näkökulma on käytännössä, ennen muuta omalle 
kouluttajantyölle, saavutettava hyöty. Lukijan oma elämänkatsomus lukukokemusten suodattajana vaikutti ja sai vaikuttaa työskentelyyn.

\section{Mikä kolahti?}

Ensimmäisessä varsinaisessa työkokouksessa kukin raportoi omat lukukokemuksensa sekä nimesi ne tutkimukset, jotka "kolahtivat" - kuten arvioryhmän itsellensä asettama kriteeri kuului. Toisella kokoontumiskerralla päätettiin keskustella seikkaperäisemmin 13 teoksesta. Kaikki valitut tutkimukset oli julkaistu kolmen viimeisen vuoden sisällä. Vaikka ajallista rajausta ei tehtykään, mielenkiintoisimmat raportit löytyivät uusimmista kirjoituksista.

Kukin lausui myös julki sen taustaryhmän ja sen intressin, jota silmälläpitäen hän tutkimuksia arvioi. Cristina Andersson nimesi omaksi viiteryhmäkseen yrittäjät, jotka pyrkivät hyviin tuloksiin menestyäkseen. Yksityiskonsulttina hänen tehtävänsä on auttaa yrityksiä tekemään tulosta ja useimmiten myös parantaa ihmisten elämänlaatua työpaikoilla. Toiseksi lähestymistavakseen hän sanoi ihmiskäsityksensä ja oppimiskäsityksensä. "Oppimiskäsitykseni on hyvin kontekstuaalinen, ja siinä vallitsee oppijan, oppimistehtävän ja oppimisympäristön triangeli. Tarkastelen tutkimuksia tämän triangelin kautta: voisinko tarjota asiakkailleni sellaista, josta olisi jollekin tässä kolmiyhteisyydessä iloa ja hyötyä. Tunnustaudun myös humanistiksi, jonka mukaan ihminen on psyykkinen, jopa henkinen olento."

Mikko Takalan lukukriteerinä oli se, millä teoksilla hän olisi valmis rikastuttamaan ammattikorkeakoulun opettajien ajattelua. Ahti Valke kertoi pitävänsä aikuisopiskelijaa ensisijaisena kriteerinään: yksilöitä, jotka osallistuvat vapaaseen sivistystyöhön erilaisten sidosryhmien ja sosiaalisten yhteisöjen kautta. Matti Hermusen viitekehyksenä ovat henkilöstön kehittäjät, suunnittelijat ja kouluttajat.

\section{Havaintoja kokonaisuudesta}

Aikuiskasvatustutkimuksen näkökulma oli viime vuosikymmenellä yksilöpsykologinen. Nyt kirjo on rikkaampi. Löytyy moraalitutkimusta, kvantitatiivista ja kvalitatiivista tutkimusta ja sosiologista hahmotusta. Vaikka tutkimusaiheiden kirjo on laajentumaan päin, joltakin osin se koettiin vielä kapeaksi. 70-luvun lopulla alettiin painottaa ammatillista aikuiskoulutusta ja se näkyy nyt tutkimuksissa ja tutkimusotteessa. Vapaan sivistystyön aihemaailmasta ei löytynyt ainokaistakaan tutkimusta ja puutetta pidettiin suorastaan ongelmana. Ahti kaipasi aikuiskoulutuksen funktion miettimistä kaiken kaikkiaan ihmisen olemassaolon filosofointia vasten.

Kokonaisuudesta arvioryhmä saattoi todeta, että vaikka valonpilkkuja löytyy muualtakin, monipuolisin ja tasoltaan vahvin on Helsingin yliopisto. Helsingin yliopiston tutkimusraporteista kuultaa lisäksi vahva ohjauksellinen panos. Turun yliopiston koulutussosiologian tutkimusyksikkö tekee systemaattisemmin kuin muut tuloksia aikaansaavaa tiimityötä.

Kuten lukija pian huomaa, keskustelu tutkimuksista inspiroi ja nostatti monia mielenkiintoisia keskustelunaiheita ohi varsinaisen tutkimussisällön. Näillekin, tutkimuksen ansiosta esiinnousseille näkemyksille, on tässä haluttu antaa sijaa.

Lehden nyt julkaisema keskusteluraportti keskittyy 13 tutkimukseen. Silti ryhmä sivusi keskustelussaan kaikkia lukupöydillä olleita tutkimusraportteja, joista muutamat päätettiin vaieta armeliaasti. Keskustelun raportoinnissa on noudatettu tutkimusten osalta aakkosjärjestystä ja keskustelun runsaudesta on poimittu lukijan kannalta vain informatiivisimmat ja kiinnostavimmat näkökannat. 
Arvioryhmä käsitteli teosta Engeströmin tutkijaprofiililla siivilöiden, joten teoksesta lausutun kolmikko jakanee oman työnjakonsa suhteessa. Yrjö Engeströmiä luonnehdittiin Seppo Kontiaisen rinnalla toiseksi meidän kansainvälisen mittaluokan tiedemieheksemme, ja työssä kiitettiin sen sytyttävyyttä, lukuarvoa kantaaottavuudellaan ja kielellistä asua. Työn jälki on huippuammattilaisen.

\section{MIKKO}

Tällä kirjalla on rohjettu maallistaa tuomarit lääkärien ja pappien tavoin! Miten mielenkiintoista nähdä, että niinkin jumalaiset ja viisaat ihmiset kuin tuomarit voivat toimia niin alkeellisella tavalla ja omata työkäytännöissään niin valtavia puutteita. Tähän tutkimukseen oli siis yhteiskunnallinen tarve.

Ammattikorkeakoulun opettajan kannalta se on loistava tutkimus, missä teoria toimii ammattilaisen työkaluna. Sen ajatuksellinen kulku on selkeä ja siinä saadaan aikaan tuloksia. Eikä kukaan varmasti aseta kyseenalaiseksi sitä, etteikö tässä olevan ymmärtämisen metodin kautta voitaisi vaikuttaa asioihin.

Nuori tutkija joutuu osoittamaan lukeneisuuttaan ja teorianhallintaansa, mutta Engeströmin ei tarvitse todistella osaamistaan rekvisiitalla. Hän liikkuu ammattilaisena hyvin, hyvin vaikeassa maastossa, pystyy jäsentämään sitä, kaivamaan sieltä kipeitä asioita esiin ja vaikuttamaan niihin. Kääntöpuoli on tietysti se, että kehittävään työn tutkimukseen aiemmin perehtymättömän voi olla hivenen vaikeaa pysyä mukana. Omassa oppilaitoksessani on turvallisuuspäälliköiden koulutusohjelma ja sille alalle on miltei mahdotonta löytää sopivaa materiaalia. Tämän kirjan kautta he voivat tutustua kerrassaan oivallisesti kehittävän työntutkimuksen maailmaan.

\section{MATTI}

Alioikeudet uuden työtavan kynnyksellä kuuluu myös minun suosikkeihini. Minua suorastaan innostaa sen ote ja ajattelutapa. Se on tiukan teoreettinen, mutta ankkuroituu samalla käytäntöön. Minua miellyttää kovin tällainen toiminnan teorian ote. Teos on selkeä ja tyylikäs. Toinen seikka on sitten se, lukevatko tätä muut kuin oikeuksien kehittämisestä kiinnostuneet. Ellei, se on sääli, sillä teoksella on annettavaa aihepiirinsä ulkopuolellekin. Kannattaisi lakea ainakin johdanto ja johtopäätökset.

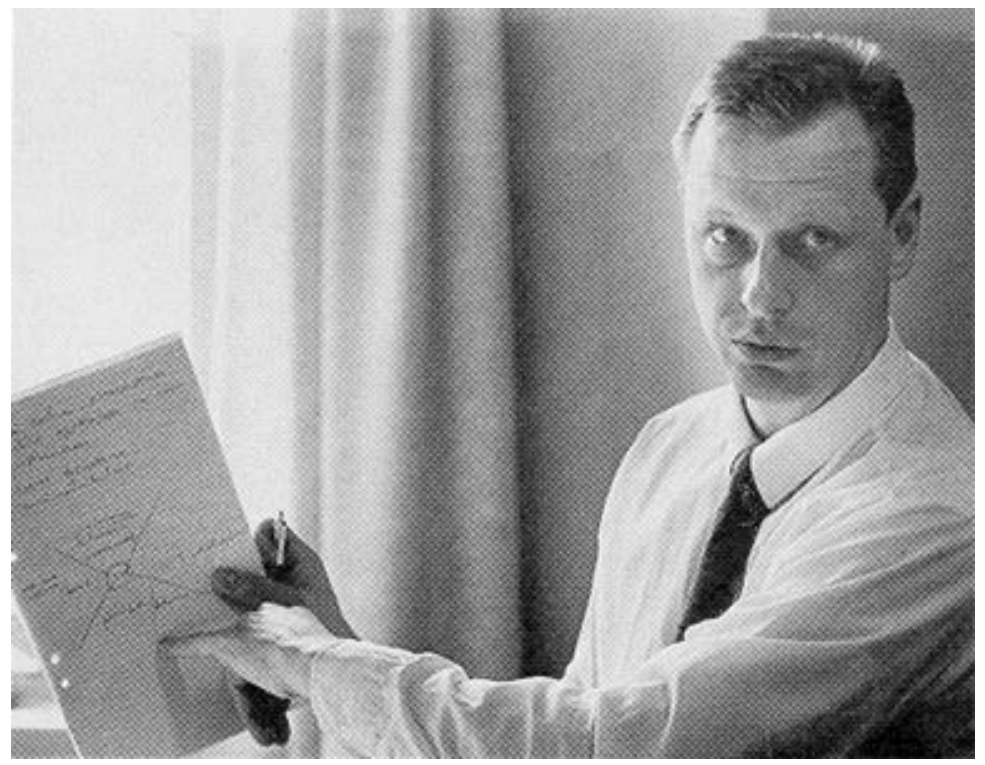

"Teoria toimii ja kaiken lisäksi saadaan aikaan tuloksia", kehuu Mikko Takala.

\section{CRISTINA}

Olen samaa mieltä. Varmaankaan oma sidosryhmäni ei tartu tähän kirjaan, vaikka itse voin soveltaa sitä työhöni, koska siinä on annettava moniin työyhteisöihin.

\section{AHTI}

Yrjö Engeström. on melkoinen vaikuttaja ja ollut sitä jo 60-luvulta lähtien. Aikoinaan mm. kognitiivinen oppiminen tuli meillä käytäntöön Engeströmin kirjojen kautta. Minulla itselläni on varsin erilainen maailmankatsomus ja -näkemys kuin Engeströmillä ja olen ihmistyyppinä aivan toisenlainen. Engeström 
näkee asioita järjestelminä. Minä lähden erilaisista tieteenfilosofisista lähtökohdista ja myös tunteiden merkityksestä. Arvostan häntä, mutta hän ei erityisemmin näkemyksineen kosketa minua, sillä vain jokin osa omaa elämääni kulkee Engeströmin esiin nostamia ratoja. En kiistä niiden käytännön hyötyä.

On kenties hassua sanoa tutkijasta ja professorista, että hän on ammattimies. Mutta näin todella on: teos on ammattitaidolla tehty. Siinä on tuotu keskeiset asiat esille ilman turhia löpinöitä, kuitenkin kriittisesti. Eikä hänen tarvitse kuluttaa sataa sivua lähderepertoaariin.

\section{MIKKO}

Kuinka moni professori tutkiessaan - esimerkiksi alioikeuksia tai lääkäreiden työtä - tutkii tavoitteena korjata asioita paremmaksi? Aika monelta taitaisi tulla sössöä. Monet ovat sen sijaan loistavia siinä, että tekevät tutkimuksellaan laadukasta TIEDETTÄ.

Ikääntyminen ja työ. Toimituskunta: Jorma Kuusinen, Eino Heikkinen, Pekka Huuhtanen, Juhani Ilmarinen, Juhani Kirjonen, Isto Ruoppila, Tapio Vaherva, Olli Mustapää ja Sirkka Rautoja. WSOY ja Työterveyslaitos 1994, $484 \mathrm{~s}$.

Jyväskylän yliopiston kasvatustieteellisen tiedekunnan nimeämä teos Ikääntyminen ja työ on kaupallisen kustantamon ja yleishyödyllisen tutkimus- ja koulutuslaitoksen yhteinen julkaisu, jonka toimitus- ja kirjoittajakunnan muodostaa pääosin tiedeväki. Teos herätti paljon ihastusta ja kiitosta Kokonaisuutena se koettiin teokseksi, jota voi kuitenkin lukea sieltä täältä oman kiinnostuksensa mukaan.

Kirjan arvoa nostaa se, että se sopii kaikenikäisille aikuisille. Erityisesti kiitettiin Yrjö-Paavo Häyrysen artikkelia Henkiset kyvyt, itsemäärääminen ja organisaation muutos. Myös Pauli Juutin ja Päivi Siltalan artikkelit saivat osakseen kiitosta. Joukosta löytyi myös lonkalta kirjoitettuja osuuksia, mitkä saattavat erehdyttää jotakuta lukijaa vetämään sen perusteella johtopäätökset koko kirjasta ja jättämään tutustumisensa silleen.

Kirjan rakenne ja selkeä jäsennys miellyttivät. Kaaviot ja marginaaliotsikot ovat selkeät ja lisäävät luettavuutta. Rivakkalukuisuuden selitykseksi sanottiin ammattitaitoinen toimitustyö, missä juuri luettavuutta on arvostettu. Kirja, joka soveltuu yleissivistävänä teoksena kenen tahansa hyllyyn, totesi arviointiryhmä yksituumaisesti.

ARJA

Kirjassa on ihmisen näkökulma, ihmisen elämänkaari ja elämäntilanteet suhteessa työelämään. Sinänsä kirja ei aseta työkulttuuria kyseenalaiseksi, mutta tuo puheenvuorona uusia näkemyksiä siitä. Mikä on sen suhde aikuiskasvatukseen ja siihen, että osa ihmisistä joutuu viettämään ison osan elämästään työttömänä? Myös vapaan sivistystyön foorumeilla saatu sivistys täytyy voida lukea sivistykseksi myös muilla alueilla.

Kirja sopii mielestäni vapaan sivistystyön, kuten kansalaisopistojen opettajille ja kouluttajille, mutta voin suositella sitä myös työelämän kouluttajille tai yliopistossa tuleville tutkijoille. Käsikirjamaisuutensa vuoksi sitä voi lukea valikoiden ja se sopii monentyyppisille lukijoille.

Arviomme eräiden artikkeleiden epätasaisuudesta nostaa esiin myös tieteenfilosofisen kysymyksen siitä, onko todellisuus tekstissä vai lukijassa. joidenkin meistä kokemuksen mukaan tietyt nimeämämme artikkelit eivät ole relevantteja. Mutta se ei poista mahdollisuutta, että joku muu lukija löytääkin siitä näkökulmia. Siksi en antaisi aina painoa sille, onko jokin teksti "hyvä" tai "huono". joskus on ihan hyvä lukea myös "huonoa tekstiä", koska kriteeri on lukijassa. Todellisuus on siis paradoksaalista.

Ikääntyminen ja työ on kaiken kaikkiaan elegantti kirja, hyvä myös käteen!

\section{AHTI}

Ei kirjaa tarvitsekaan lukea kannesta kanteen. Uusi lukutaito on sitä, että osaa ottaa kirjoista tietoa sieltä täältä. Silloin selkeä jäsennys nousee keskeiseksi. 


\section{CRISTINA}

Tällä kirjalla on annettavaa siksi, että se käsittelee ihmistä kokonaisvaltaisesti. Ihmisen elämänkaaren eri vaiheissa on monia asioita tapahtumassa yhtä aikaa. Elämä on kuin sateenkaari, ei putki. Siksi teos on aikuiskasvatustyötä tekeville erinomainen tukimateriaali, joka avartaa näkemystä aikuisesta oppijana.

Jo kirjan nelisivuisesta sisällysluettelosta oppii paljon. Se voisi itsessään olla terveellistä luettavaa autoritaarisille johtajille.

\section{MIKKO}

En jaksa enää innostua perusteoksista tyyppiä Tiedonportaat. Silti kirja on kiistatta hyödyllinen ammattikorkeakouluopettajan perustyökaluna. Soveltuvuudessa joka käteen on samalla kirjan voima ja heikkous.

Vanhenemisesta kirja nostaa esiin positiiviset mahdollisuutemme. Tulemme kukin ikään, jolloin iän kartuttama viisaus nousee tärkeäksi eli nojaudumme enemmän siihen, mikä elämässä on itse kullekin lopulta tärkeää. Olen vakuuttunut siitä, että tulevaisuudessa yhteiskunnan "vanhoilta ja viisailta" kysytään neuvoa. Niin on pakko käydä.

\section{Liisa Joronen 1993. Ammatillisen kasvun edellytykset organisaatiossa. Tutkimuksia 135. Helsingin yliopiston} kasvatustieteen laitos, väitöskirja, 258 sivua.

Liisa Jorosen väitöskirja poikkeaa muista Helsingin yliopiston samoihin aikoihin ilmestyneistä väitöskirjoista, koska sitä on tehnyt työnsä ohessa henkilö, jonka kokemus ja osaaminen on käytännön yrittäjyydessä. Tästä katsottiin johtuvan myös sen, että tutkimusohjauksen merkitys tunnistettiin ohuemmaksi kuin monissa muissa.

Liisa Joronen on profiloitunut julkisuudessa siivousalan yrityksestään. Väitöskirja nostattikin vilkkaan keskustelun tutkimuksen muodoista. Uskottiin, että oikeaoppisen väitöskirjan vaatimukset ovat kahlinneet tekijää, jolla väitöskirjaa vapaampaa muotoa käyttäen olisi voinut olla enemmän annettavaa. Tutkimuksen pelisääntöjen noudattaminen tekee työstä kuivan. Keskusteltiin myös työelämässä kiireisen, työn ohessa tutkijaksi heittäytyvän naisen rooliristiriidoista ja niiden heijastumisesta tulokseen ja tasoon. Rinnastus Kaisa Kautto-Koivulaan tuli mieleen tilaamatta - ja sitä myötä kysymys lahjakkuudesta tutkijana. Kaisa Kautto-Koivula onnistui erinomaisesti siinä, missä Liisa Joronen paljon huonommin.

Väitöskirjan rakenteet ovat arvioryhmän mukaan soveltuneet huonosti tutkijalle, joka käytännön ihmisenä ei ole osannut hyödyntää tieteellisen tutkimuksen raameja samalla tavalla kuin joku tieteellisemmin suuntautuva tutkija. Heikkoudeksi luettiin myös se, että väitöskirjaan on kirjoitettu sisälle kaikki, ikään kuin tekijänsä lukeneisuuden vakuutteluna.

Kaisa Koutto-Koivula 1993. Degree. Oriented Professional Adult Education in the Work Environment. Acta Universitatis Tamperensis, ser A vol, 390 . Tampere. 340 sivua \& liitteet.

Vuoden tutkimukseksi 1993 valittua Kaisa Kautto-Koivulan laajaa väitöskirjaa luonnehdittiin "upeaksi duuniksi". Se, että joku pystyy olemaan täysipäiväisessä työssä ja tekemään työnsä ohessa niin korkeatasoisen tutkimustyön, sai raadin kunnioituksen osakseen. Työn jäsennyksen kirkkautta kiiteltiin eli kuten Matti Hermunen totesi: "Neljä sataa sivua eikä yhtään sekava. Se on hyvä suoritus."

\section{CRISTINA}

Monet yritykset, joilla oli vielä pari vuotta sitten buumi kouluttaa työntekijöitä pätevyyshakuisesti, ovat hakeutumassa siitä pois, koska näin saatu pätevyys ei lopultakaan ole riittävän laaja-alaista. Omia kohdeyrityksiäni ajatellen tällä tutkimuksella ei ole muutamia hyviä

knoppeja lukuunottamatta laajempaa käyttöä, koska niillä ei ole Nokian kaltaista koulutusohjelmaa, siis kouluttaa insinööreistä diplomi-insinöörejä ja teknikoista insinöörejä. Siihen käyttöön Kaisa 
Kautto-Koivulan tutkimus lienee hyvä käsikirja ja sen avulla voidaan varmaan ennakoida ongelmia, joita syntyy yrityksen pyrkiessä laaja-alaiseen koulutukseen.

\title{
MATTI
}

Minä puolestani olen yrityksessä, joka miettii tällaisen koulutuksen käynnistämistä. Koulutus näyttää hakeutuvan entistä enemmän pois oppilaitoksista ja niiden rinnalle tulee omaehtoista kouluttautumista ja oppimista organisaatioissa. Siihen käyttöön tämä on hyödyllinen ja hyvä case.

\begin{abstract}
AHTI
Minun on vuorostaan vaikeaa löytää tälle arkikäyttöä. Mutta jos yrityksessä mietitään tämäntyyppisiä kysymyksiä tai tutkija miettii, millaisia tutkimusotteita voisi olla, tämä työ tarjoaa perinteiseen tutkimukseen verrattuna hyvin mielenkiintoisen tutkimusotteen. Lisää glamouria luonnollisesti syntyy siitä, että tutkimus on tehty hyvin ja että Nokia on eräänlainen yritysten keulakuva, mielikuva Suomen noususta osaamisella. Englanninkielisenä se sopii juuri Nokian kansainvälisyyteen.
\end{abstract}

Mielenkiintoista ja tärkeää tässä tutkimuksessa on yksityiselämä taustamuuttujana. Tutkijalla itsellään on ihmisenä ja äitinä, ehkä myös naisena, kaikki ne roolipaineet ja rooliristiriidat, joita on täytynyt olla selvitäkseen näin laajasta työstä.

\section{MIKKO}

Tämä työ painii omassa sarjassaan ja on todella hieno, korkeatasoinen tutkimus. Yhteiskunta tarvitsee esimerkkejä myös tällä tavalla menestyvistä naisista, jotka tuovat keskusteluun oman sosiaalisen viitekehyksensä.

ARJA

Kaisa Kautto-Koivulahan teki kirjoitustyön aamun pimeinä tunteina, työpäivää venyttämällä, jotta perheenäidin ja pienten lasten rooli tulisi sekin hoidetuksi. Tällaista tutkimustyön esittelyä kaikkine kurjuuksineen ja ihanuuksineen voisi enemmänkin harrastaa kasvatustieteen puolella. Tunnemme kyllä filosofit yksityiselämää myöten, mutta kasvatustieteilijät ovat alue, missä tutkijoita ja ammattitaitoa ei personoida.

Mitä tulee itse työhön, siinä on paljon sellaista, mikä ansaitsisi suomennoksen ja sitä kautta laajempaa käyttöä. Tässä, kuten monessa muussakin tutkimuksessa olisi hyödyksi käytännönläheisempi versio tarttumapinnan laajentamiseksi.

\section{Jukka Koro 1993. Aikuinen oman oppimisensa olhjaajana. Jyväskylä Studies in Education, Psychology and} Social Research 98. Väitöskirja, 178 s.

Jukka Koron väitöskirjassa koettiin teorian ja empirian välinen kuilu suurehkoksi eli kuten Ahti Valke totesi, teoreettinen lähtökohta on mielenkiintoinen, mutta teoria ei näy enää tutkimusotteessa. Yksi ratkaisu olisi arvioryhmän mielestä ollut kokonainen tutkimusryhmä, joka olisi kenties onnistunut pureutumaan tematiikkaan paremmin siinä, missä yhden ihmisen resurssit loppuvat. Kun käsiteltävänä on niinkin syvällisiä kysymyksiä kuin elämäntarkoitus, täytyy olla melko tekijä selvitäkseen yksin.

\section{ARJA}

Vankka tutkimus, jossa on 1970-luvulta peraisin oleva teoria ja kyselymittari, mutta sen lisäksi tutkimusta on laajennettu kvalitatiivisen teemahaastattelun puolelle, joka tuo raporttiin elävyyttä. Mielestäni tämä on kuitenkin puhtaasti tutkijoille kirjoitettu ja heille avautuva raportti. Se on perusteellisesti tehty, sillä on uutta annettavaa, eikä ole kovin kuivakaan luettava. Mutta en usko, että aikuiskasvattaja työelämässä, henkilöstöpäällikkö yrityksessä tai opettaja kansanopistossa ottaisi tämän lukulistalleen.

Itse voisin uppoutua sen empiiriseen osaan kaiken muun unohtaen, mutta se johtuu siitä, että tässä on pienen pieniä minua kiehtovia nyansseja ja olen saanut vankan kvantitatiivisen koulutuksen. 


\section{MIKKO}

Minun prosessini tämän tutkimuksen osalta oli se, että olin ensin ihastuksissani kaikesta alkuosan potkusta, sen loistavasta laaja-alaisesta pohdinnasta. Mutta sitten hiipi pettymys: kirjassa ei ollutkaan sitä, mitä luvattiin. Ensimmäinen kolmannes oli mahtava, mutta loput sitä sen seitsemännentoista kerran pestyä pyykkiä, josta ei enää edes lika irtoa, vaan joka kuluu vaan. Itseohjautuvuuskin oli vähän semmoista ja tämmöistä.

Paradigma, tiedeyhteisö ja menetelmät ovat hallinneet tutkijaa ja olleet hänelle kuin panta päässä. Metodologinen laajennus kvalitatiivisen puolelle on lähinnä paikkaavaa ja osoittaa lähinnä metodien hallinnan. Luokituksessani tutkimus on sarjaa "Ei uutta auringon alla" mutta alku, se on upea!

\section{MATTI}

Oma myönteinen suhtautumiseni liittyy juuri tuohon alkuosaan: hurmaannuin siis selkeään, uutta tietoa antavaan johdantoon. Tutkimuksessa on käsitelty monipuolisesti itseohjautuvuutta ja sen suhdetta monimuoto-opiskeluun. Humanistinen ihmiskuva on ihan mukavasti tuotu esiin. Mielestäni se on selkeänoloinen tutkimus, mutta liian paljon tutkimus, jotta käytännön ihmiset tulisivat lukeneeksi ja hyödyttäneeksi sen alkuosan.

\section{AHTI}

Palaan jälleen siihen (ryhmän aiempia keskusteluja, toim. huom.), ettei teksti ole niin tärkeä kuin lukija. Tekstistä löytyy sitä enemmän, mitä enemmän lukijalla on näkemyksiä ja skeemoja kyseisestä asiasta. Tutkimuksissa on yleensä kiinnostava teoreettinen osa, kuten Jukka Koronkin väitöskirjassa. Mutta mitä sitten teoriasta saadaan irti, se on usein pettymys. Tulokset ovat tyyliä "liikenteen melu on suurempi kadun puolella". Tämä lässähdys tapahtuu mielestäni useimmissa käsittelyssä olevista tutkimuksista, niin myös Korolla. Poikkeuksena on Kautto-Koivulan tutkimus, missä ei tapahdu mitään lässähtämistä, vaan siinä empiirinen osa on yhtä painava kuin teoriaosakin.

Esimerkiksi Koro on ottanut perusasetelmaansa hyvin mielenkiintoisella tavalla mukaan Lauri Rauhalan ajattelua (kehollisuus ja situationaalisuus), mutta ei se näy enää empiirisessä osassa.

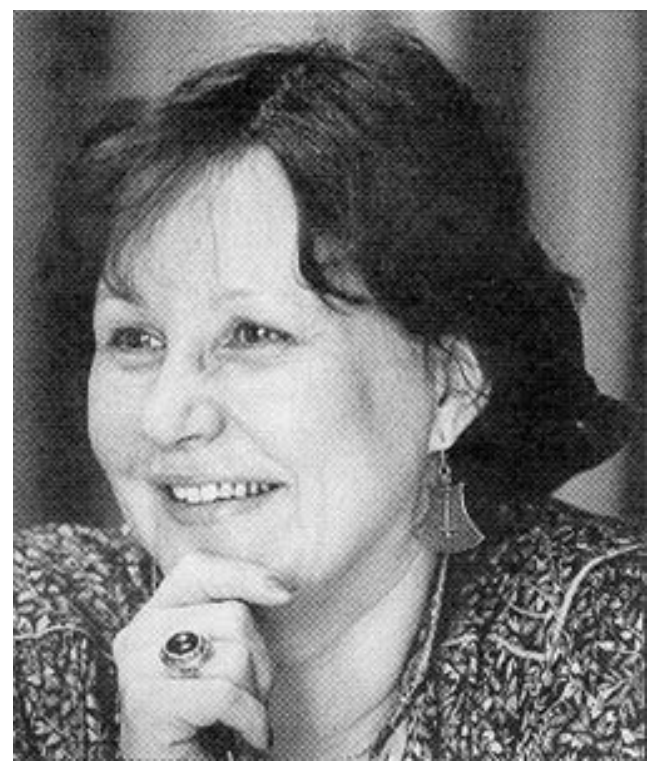

"Vankka tutkimus, missä on 1970-luvulta peräisin oleva teoria ja kyselymittari", tiivistää Arja Puurula Jukka Koron väitöskirjan.

\section{CRISTINA}

Koro kirjoittaa: "Tuloksellisella opiskelulla näyttäisi olevan vaikutusta minäkuvan kehittymiseen." Näinhän asia on. jos ihmisen minäkuva kehittyy, hän pystyy tekemään työnsä paremmin ja opiskelemaan paremmin. Siksi tämä on merkittävä tutkimus niille, jotka miettivät, miten edistää koulutusta organisaatiossa. Viesti on se, ettei sillä ole sinänsä merkitystä, MILLÄ TAVALLA opiskelu tapahtuu, kunhan opiskelija itse kokee sen 
TULOKSELLISEKSI. Koron viesti on, monimuoto-opiskelu ja monivälineopiskelu antavat opiskelijalle mahdollisuuden hakea erilaisia keinoja päästä tuloksellisuuteen. Vaikka tässä on käytetty hirveästi sivuja tämän oivalluksen antamiseen, koen sen kirjan ytimeksi.

En suosittele tätä kirjaa luettavaksi, mutta mielelläni työssäni kerron sen ydinajatuksista.

Ritva Lindroos 1993. Työ, koulutus, elämänhallinta. Tutkimuksia 136. Helsingin yliopiston kasvatustieteen laitos. Väitöskirja, 331 sivua.

\section{MIKKO}

Minun kolme ehdotonta suosikkiani ovat Ritva Lindroosin, Yrjö Engeströmin ja Kari Rantalaihon tutkimukset.

Ritva Lindroosilla on tärkeä näkökulma. Kasvatustieteissä tarvittaisiinkin paljon enemmän sosiologista ja kvalitatiivista otetta. Olen vahvasti yksilöllisyyden kannattaja, mutta näen, että vaikeissa kasvatustilanteissa ihmistä määrää ympäristö, konteksti. Olemme ympäristömme vankeja ja samalla saamme paljon ympäristöltämme. Niinpä pitkälle viety yksilöllisyys ja yksilöpsykologia ovat eläneet aivan liian vahvoina kasvatustieteissä. Interaktioteoriat, motivaatioteoriat ja muut yksilökeskeiset näkökulmat ovat sinänsä arvokkaita, mutta niistä puuttuu hermeneuttisesta tieteentraditiosta lähtevä, ymmärtävä asianerittely. Nyt olemme selvästi murroksessa, missä rakenteet ryskyvät.

Tutkimuksessa on hajanaisuutta, sitä on kenties ollut vaikeaa saada kasaan. Mutta parasta siinä on erinomainen jäsennys ja juuri tuo sosiologinen näkemys, sekin monelta kantilta pohdittuna. Kasvatustieteilijän tehtävä yhteiskunnassa on pyrkiä ymmärtämään. ja sitä juuri tämä on.

Tunnustan hengenheimolaisuuteni Ritva Lindroosiin oman työni kautta ja koen samalla tuskaa siitä, ettei mitään tällaista ollut kasvatustieteissä olemassa silloin, kun sitä olisin itse työni tukena tarvinnut. Mainiota, että nyt Helsingin yliopistossa tuotetaan myös tällaista.

\section{Jyri Manninen 1993. Akateemiset työttömät työnhakijat. Tutkimuksia 137. Helsingin yliopiston kasvatustieteen laitos. Väitöskirja, 190 sivua.}

\section{AHTI}

Luin tämän tutkimuksen samanaikaisesti, kun olin nuorten työttömien kouluttajana. Koulutukseni kohderyhmänä oli drop out -nuoria, kun Jyri Mannisen kohteena ovat akateemiset. Koin, että samoja kysymyksiä on paljon. Elämäntilanne nousee kummassakin ryhmässä keskeiseksi. Kysymys on siis eksistenssistä, kuka olen, mihin kuulun, luotanko itseeni, millainen minäkuva minulla on.

Tutkimuksessa olisi saanut olla enemmän filosofointia. Työvoimakoulutus muutostekijänä nosti esiin ammatilliset kvalifikaatiot ja elämänhallinnan ja sen koin tässä tutkimuksessa kaikkein merkityksellisimmäksi. Elämänhallinnan näkökulma on erittäin tärkeä ja se liittyy voimallisesti myös vapaan sivistystyön lähtökohtiin. Siksi tämä teos voisi sopia myös vapaan sivistystyön opettajalle.

Jyri Mannisen tutkimuksesta nouseva jatkokysymys on, miten sitten selviydytään. Manninen olisikin voinut jatkaa selviytymisstrategioilla. Tällöin olisi ollut työttömien tyypittelyn asemasta dynaamisempaa kuvata ongelmallisuutta elämäntilanteina. Löytyisikö myös yhteisöllisiä ratkaisuja selviytymiseen, hakevia ratkaisuja, esimerkiksi vapaassa sivistystyössä? Itse asiassa meidän on pakko löytää uusia selviytymisstrategioita, myös yhteisöllisiä, jos työttömyys vakiintuu korkealle tasolle.

\section{ARJA}

Pidän Jyri Mannisen työstä, mutta vieroksun työttömien tyypittelyä. jos pidän viitekehyksenäni yritysmaailmaa, sille tämä on vieras tutkimus, mutta korkeakoulumaailmalle tutkimuksella on jo paljonkin annettavaa. 


\section{MATTI}

Tämä tutkimus sopinee yliopistoihmisille ja niille, jotka haluavat perusteellisemmin paneutua tutkimuksen aihemaailmaan, siis työttömyyteen. Omassa työssäni sille ei sen sijaan ole käyttöä.

\section{MIKKO}

Mielestäni kasvatustieteilijän tärkein intressi on YMMÄRTÄMISEN INTRESSI. Se näkemys on aikanaan johtanut minut kvalitatiivisen metodiikan lähteille. Kun näen taulukoita, koen puistatusta, koska ei elämää voi puristaa taulukoiksi kuten kansantaloutta. Siihen tarvittaisiin ainakin hyvin suuret populaatiot.

Jyri Mannisen tutkimus on tehty vahvassa ohjauksessa. Kun keskustelukriteerinämme on se, kenelle antaisin ja mitä, antaisin omille opettajilleni mieluummin Ritva Lindroosin tutkimuksen kuin Jyri Mannisen. Kuitenkaan niitä ei pitäisi lukea erikseen, vaan kaikkia kolmea työttömyyttä käsittelevää tutkimusta toisiaan täydentävänä lukupakettina. Siitä tullaankin siihen, että Helsingin yliopiston kasvatustieteellisessä vallitseva paradigma on hedelmällinen: hyvä ohjaus, moninainen yty, asioiden tarkastelu erilaisista lähtökohdista sekä moraalitutkimusta tarkastelua täydentämässä.

\section{CRISTINA}

Olen ollut töissä ammatillisessa kurssikeskuksessa ja siksi tämä aihe, siis työttömät, työttömyysuhan alaiset ihmiset ja koulutus, on minulle läheinen. Tutkimus avartaa näkemään työttömyystilanteessa erilaisia vaiheita. Toisaalta se ei mene siitä kaaresta kauemmaksi, eteenpäin.

Päivi Naumanen 1994. Tiedon, taidon ja vallan tiellä. Miesten ja naisten kouluttautuminen ja työ. Raportteja 22, Turun yliopiston koulutussosiologian tutkimusyksikkö, 279 sivua.

Päivi Naumasen raportissa on hyödynnetty valtakunnallista isoa tutkimusaineistoa, kuten monissa muissakin Turun yliopiston koulutussosiologian tutkimusyksikön tällä vuosikymmenellä tuottamissa raporteissa. Tutkimus viritti arvioryhmässä myös vilkkaan keskustelun sukupuolisuudesta.

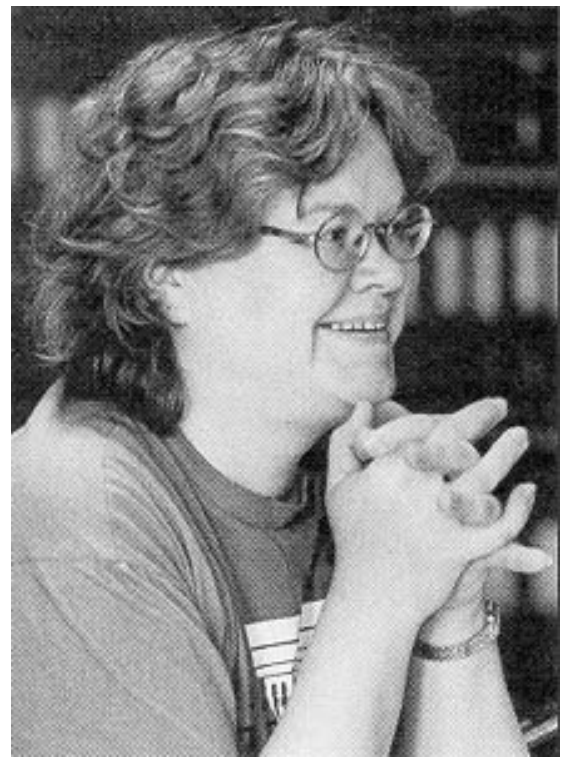

"Tästä tutkimuksesta käy ilmi pallon sellaista, mikä turhauttaa naisia työpaikoilla", sanoo Cristina Andersson.

\section{ARJA}

Päivi Naumasen tärkeä raportti on minun suosikkini tai ainakin yksi vankoista suosikeista. Päivi Naumasen työssä mielenkiintoisinta on historiallinen alkuosa. ja itse pidän hyvänä koko teemaa. Aikuiskoulutus on aina ollut tärkeämpää naisille kuin miehille. Aikuiskoulutuksesta on tullut naisten tie tietoon ja taitoon, kilpailukyvyn parantamiseen naisten itselleen soveliaimmiksi kokemilla aloilla.

Vaikeimmin luettavaa tässä tutkimuksessa ovat yksittäiset taulukot, jotka sisältävät valtavasti detaljitietoa. Huomionarvoista Päivi Naumasen työn julkistamisessa olivat näyttävät lehdistöreferaatit. Sen keskeinen anti ylitti valtakunnan uutiskynnyksen. Miten perinteiset yliopistot oppisivat saman perustiedon 
julkistamistaidon, onkin iso kysymys. Oma työ on osattava markkinoida, muuten se jää aivan liian suppean lukijakunnan tiedoksi.

\section{AHTI}

Mielenkiintoisinta tässä on juuri aihe ja erityisesti historiallinen johdanto-osa. Siinä ei ole mitään teoreettisesti luovaa, mutta se on sinällään hyvin ansiokas. Tämä tutkimus on myös ainoa, missä aikuiskasvatuskenttää käsitellään kokonaisuudessaan ja missä myös vapaa sivistystyö tulee esille.

Pidän tutkimuksen mies-naiskäsittelyä ansiokkaana ja hienona. Tietyllä tavallahan se on tuttua, mutta toisaalta miehen elämä luo harhoja, joita ei jaksa havainnoida, vaan elämää usein pitää juuri sellaisena kuin se miesten näkökulmasta näyttää. Olen siksi viime vuosina kuunnellut kiinnostuneena naisia ja lukenut naistutkimuksia, jopa äärifeministejä, oppiakseni jotain uutta todellisuudesta. Naumanen käsittelee asioita viileästi ja perustellen, ja siksi sitä voi lukea suuttumatta. Se saa miettimään asioita uudella tavalla, myös suhdettaan omaan perheeseensä. Vaikka luuleekin itseänsä tasa-arvoiseksi, huomaamattaan pitää kiinni monista perinteisistä miehisistä etuoikeuksista. (heitto taustalta: ”Aläkä luovu niistä!”)

Tunnen viehtymystä idän filosofioihin. Myös tähän tutkimukseen liittyy filosofisia ulottuvuuksia: molemmat meissä, jin ja jan, ovat tärkeitä kuunnella.

Päivi Naumasen tutkimus antaa myös tärkeän tarkastelukulman elämänhallinnan teemaan. Ei ole kysymys siitä, että ihmiset olisivat samalla viivalla, vaan yhteiskunnalliset erot on tosiasia. Sukupuolijakauma ei ole ainoa ero, mutta kylläkin merkittävä. MILLAISIA RATKAISUJA meidän tulisi löytää, tunneperäisestikin, koska on kysymys olemassaolosta, eksistenssistä ja kaikesta siitä, mikä liittyy lähiomaisyhteisöön, elämän jatkuvuuteen ja yksilön omiin kokemuksiin.

\section{CRISTINA}

Riemuitsen tästä tutkimuksesta. Olen aiemmin puhunut triangelista, mihin liittyy elämänlaatu työpaikalla. Naisten elämänlaatu EI OLE työpaikalla. Tästä tutkimuksesta käy ilmi paljon sellaista, mikä turhauttaa naiset työelämässä, joka ei suo naisille samoja oikeuksia ja mahdollisuuksia kuin miehille.

Naiset siis kouluttautuvat, mutta tekevät sen yksityisajallaan. Törmään työelämässä jatkuvasti erilaisiin naisten tarinoihin tiedon, taidon ja vallan kokemusmaailmasta, ja siksi tämä raportti on niin verrattoman tärkeä.

\section{MATTI}

Päivi Naumasen tuo vastustamattomasti esille sen, että tasa-arvoasiat eivät ole kunnossa. johdanto on yleissivistävä ja lukijaystävällinen. Mutta syystä, jota ei osaa täsmentää, tämä tutkimus ei minulla kuitenkaan nouse päällimmäisten joukkoon. Ehkä syynä on se, että siinä on otettu iso aineisto ja ryhdytty ajamaan sitä, jolloin siitä ei voi nousta esiin mitään kovin hätkähdyttävää. Mutta tutkimuksen ansioita en kiistä. Myös aihe on tärkeä.

Kun totesimme Yrjö Engeströmistä, että hän tekee ammattityötä, niin kyllä tästäkin välittyy sama: asialla on ammattilainen.

Kari Rantalaiho 1994. Huomautuksia osaamisesta. Kasvatustieteiden tiedekunnan selosteita 50, Joensuun yliopisto, 70 sivua.

Kari Rantalaihon suppea Huomautuksia osaamisesta herätti enimmältään ihastusta, mutta myös epäilyä. Matti puki arvioryhmän kokeman epätietoisuuden epätietoisuudeksi siitä, onko kyseessä "tupafilosofia" vai tosi kova uusi juttu. Työ sai ryhmältä kuitenkin voimakkaan positiivisia luonnehdintoja: pirteä, omaperäinen, tervetulleella tavalla poikkeava. Mikon lukukokemuksissa Huomautuksia osaamisesta sijoittui kolmen suosikin joukkoon.

Samoin kuin Kaisa Kautto-Koivulan ja Yrjö Engeströmin tutkimukset myös Kari Rantalaihon työ inspiroi arvioryhmää etsimään kasvoja ja persoonaan työn takaa: On kysymyksessä henkilö, joka on katsellut ja kokenut elämää monesta kulmasta ja jolla on VARAA tehdä juuri senmittainen ja senlaatuinen tutkimus kuin luonnostaan oli tullakseen. Työ ei ole puristetta. 


\section{AHTI}

Tässä työssä on keskustelun avauksena monta hyvää teemaa, monet niistä muualtakin tuttuja, mutta yhtä kaikki hyvin yhteen koottuina. Voisin nostaa sieltä vapaan sivistystyön opettajille ajatuksia herättäviä teemoja, mm. ihmisen yksilöllisyyden, itseohjautuvuuden suhteessa työelämän lainalaisuuksiin. Tai johtamistaidon järjestelmät ja kulttuurit, jotka voivat olla ristiriidassa Jukka Koron esittämän itseohjautuvuuden kanssa ja olla päinvastoin yksilön oppimisen esteinä.

Rantalaihon työ on siinäkin mielessä muihin nähden erilainen, että se ei pyri empiristisesti ratkaisemaan jotakin, vaan aloittaa keskustelun, josta VOI syntyä jotakin.

\section{CRISTINA}

Mielestäni on erinomaista, että ihminen uskaltaa lähteä kirjoittamaan jostakin sellaisesta, josta hänellä ei ole itselläkään vielä täyttä ymmärrystä. Oppiminen on, kuten hän itsekin sanoo, kvantinomaista, haparoivaa. Hänkin on hakemassa tässä jotakin, jossa liikutaan vähän kuin sumussa. Mutta se, että tiedetään jotain IHAN VARMASTI, se on jo. Se missä vielä haparoidaan, se vie yhteiskuntaa ja asioita eteenpäin ja on tulevaisuutta.

\section{MATTI}

Se ei ole vain vielä - niin, voisiko se edes olla -- valmis! Se kai siinä meitä kaikkia kiehtoo.

AHTI juuri se minua Rantalaihon työssä tieteellisessä mielessä viehättää, koska elämä ON EPÄVARMAA ja kuitenkin monissa yliopistollisissa tutkimuksissa heijastuu se kuva, että maailma olisi jotenkin varma. Tämä on tärkeä paradigmallinen näkökulma. Yliopistoissa tehdään yleensä vannoja tutkimuksia - ja saadaan sitten triviaaleja tuloksia tyyppiä "moniin asioihin on monia syitä". Tässä työssä on selkeämpi teoreettinen ote kuin ensilukemalla edes havaitsi, viisiosainen malli (viestivä verkko, tottumus, kontekstuaalisuus, miten ja miksi sekä ympäristösuhde) ja sen vertaaminen osaamisen tasoihin (kehittyvä aloittelija, noviisi, osaava suorittaja, taitava suorittaja ja ekspertti). Pohjana voi olla se, että kun Engeström ja kumppanit toivat aikoinaan kognitiivisen oppimisen, se toi myös oppimiseen uudenlaisen sisällön. Osaamista voidaan siis myös eritellä osiin ja analysoida. Rantalaihon työssä on kuitenkin uudenlainen lähestymistapa oppimiseen, mukana on sosiaalinen viestintä- ja verkkoajattelu.

Hän käsittelee myös tietoteknistä verkkoa ja tietoteknistä osaamista. Siinähän on tyypillistä, että ihmiset joutuvat kokemaan turhautumisia laitteiden kanssa - myös laitteita hyvin tuntevat. joskus siis eksperttiys saattaa näyttää siltä, ettei hallitse asiaa, vaikka hallitsee sen erinomaisesti. ja joskus jokin suoritus näyttää automaattisen hienolta, vaikka kysymyksessä onkin hyvin rajattu osaaminen. HYVIN mielenkiintoista tässä ajassa!

\section{ARJA}

Rantalaiho uskaltaa esittää kysymyksiä, vieläpä simppeleitä. Tämäntyyppistä esittämistapaa ei löydy yhdestäkään muusta tutkimuksesta. Ehkä juuri taito kyseenalaistaa aikaansaa viehättävyyden, joka nostaa tämän työn ohi lähdeluettelon ja käytettyjen viitteiden. Tämä on laajennettu essee, ja esseehän on syvästi hallittua, syvästi koettua, omakohtaista.

\section{MIKKO}

Minulle Rantalaihon työ oli lukulöydös! Osaamisen ongelmahan on ammattikorkeakouluissa kuumin puheenvuoro, sillä käymme identiteettikamppailua, missä emme ole yliopistoja, emmekä enää opistoja. Voin antaa tämän sairaanhoidon opettajalle, kaupallisten aineiden opettajalle, käsi- ja taideteollisuusaineiden opettajalle, ravitsemusalan opettajalle ... se sopii joka käteen. Se on poikkitieteellinen, universaali ja silti tarkkanäköinen ja kohdentuva. Sen näkökulma ei ole totutun tuttu, vaan uusi ja raikas.

Tämä vihko on loistava ajatuksellinen erottelija, missä pystytään jäsentämään ajattelua ja tekemään se uudesta näkökulmasta. Esimerkiksi lopussa oleva johdattelu egoistiseen ja altruistiseen ajatteluun on loistava. Tähän pitäisi nyt saada praktinen, caseja sisältävä jatko-osa. Joensuussa näytetään tehtävän rajat ylittävää kasvatustieteellistä työtä. 


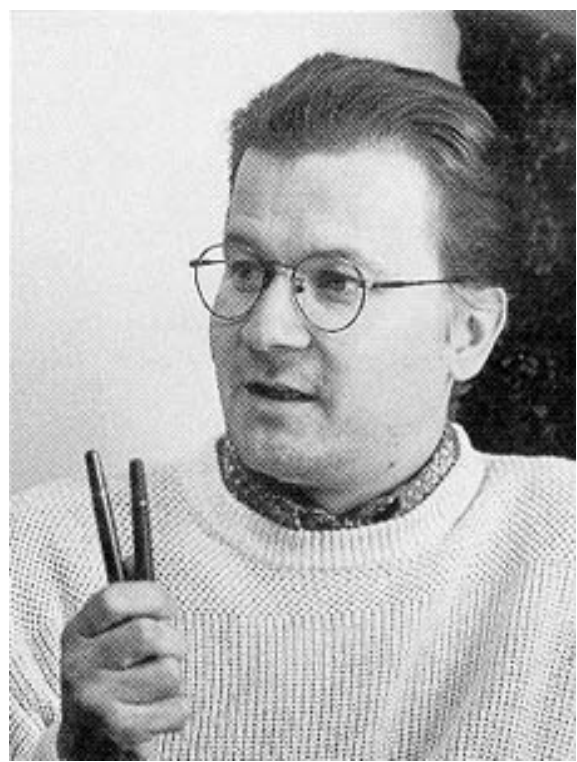

"Elämähän on epävarmaa, ja kuitenkin monista yliopistollisissa tutkimuksista heijastuu se kuva, että elämä olisi jotenkin varmaa", muistuttaa Ahti Valke.

Matti Parjanen (ed.) 1994. Outside the Golden Gate. Prospects and Comparisons In Finnish Adult Higher Education. Publications A 3. Tampereen yliopiston täydennyskoulutuskeskus, 80 sivua.

Kultaisella portilla tarkoitetaan porttia yliopistollisiin tutkintoihin. Keille kultainen portti avautuu? Suppeahkon teoksen aihetta ja kysymyksenasettelua pidettiin merkittävänä: "Nyt tultiin laajemmille vesille", kommentoi Ahti niin aihetta kuin sosiologista lähestymistapaakin, jolla kysymyksen käsittely on tuotu laajasti yhteiskuntapolitiikan ja järjestelmän tasolle. Matti Parjasen kirjan aihepiirin uniikkius herätti arvioryhmässä pitkän ja innostuneen keskustelun.

\section{ARJA}

Aikuiskoulutuksessa ja kasvatuksessa tämäntyyppistä tutkimusta saisi olla enemmän. En ole missään muussa tutkimuksessa tavannut vastaavaa makrotason pohdiskelua ja kansainvälistä vertailutietoa koulutuksellisesta selviämisestä kuin tässä. Esimerkiksi Irlannin ja Suomen vertailu antaa kerrassaan maukasta tietoa mm. naisten ja miesten koulutuksellisista ja palkkauksellisista eroista.

Teos on avaus eurooppalaiseen keskusteluun, ja sitä toivoisi hallintoihmisten, poliittisten päättäjien ja kenties valistuneiden toimittajien käyttävän ottaessaan kantaa siihen, onko Suomen valitsema suunta paras vai olisiko jossain muualla harjoitettu parempi.

Mikrotasolle viety tutkimus etäännyttää meitä aikuiskoulutuksen funktioista ja perusperiaatteista sekä suhteesta yhteiskuntaan. Tämä teos miettii juuri näitä kysymyksiä ja rinnastuu siksi kiinnostavalla tavalla Kari Rantalaihon esseemuotoiseen ajatteluun.

\section{AHTI}

Elämme rajojen rikkomisen aikaa niin makrokuin mikrotasolla.

Kysymys siitä, keille kultaiset portit avautuvat, koskettaa kovastikin vapaata sivistystyötä. Vapaa sivistystyö on perinteisesti mielletty tutkinnottomaksi alueeksi. Vapaan sivistystyön kautta opiskellaan kuitenkin myös avoimessa korkeakoulussa ja siksi ristiriita perinteisen yliopiston ja avoimen korkeakoulun välillä tuntuu myös siellä.

\section{MATTI}

Tässä kirjassa otetaan esille asioita, jotka eivät ole vielä lainkaan kohdallaan. Siinä se rinnastuu Päivi Naumasen tutkimukseen, missä käsitellään tasa-arvoa, tässä taas yliopistollisia "putkia". Toisin sanoen paljo puhe ihmisen kouluttautumisesta ja mahdollisuuksien lisäämisestä ei juuri hetkauta korkeakouluja.

Onkohan niin, että niin kauan kuin me riitelemme oppimiskäsityksistä ja lyömme niillä toisiamme päähän, käymme mukavaa ja turvallista kiistelyä, mikään ei muutu ja putket pysyvät samanlaisina. Pienuudessaankin 
tämä teos kolhaisee siis peruskysymystä: on mukava miettiä, oppiiko tuolla vai tällä tavalla paremmin, kunhan et puutu oppilaitokseen ja sen systeemiin.

Työelämässä on menossa hiton suuri murros. meillä on mahdoton määrä ihmisiä, joiden työ ja tehtävät muuttuvat. Se ei ole näkemyskysymys, vaan työelämän tarpeet pakottavat muuttumaan. Työnantajan on vaikeaa kouluttaa kaikkia uudelleen, eikä se pysyisikään siihen. On päästävä eteenpäin suorasta, määrättyyn työtehtävään kouluttautumisesta.

\section{MIKKO}

Porttikeskusteluun tuo lisävirityksensä myös ammattikorkeakoulunäkökulma: suhteiden jäsentymistä joudutaan pohtimaan vielä monet kerran ja siinä tämä teos on mielenkiintoinen avaus. joudutaan miettimään myös kysymystä avoimesta ammattikorkeakoulusta. Tulevaisuuden työtä ammattikorkeakouluissa on rakentaa systeemisten kvalifikaatioiden valmennusohjelmia. Ajatellaanpa henkilöä, jolla on takanaan agronomin tutkinto ja siihen tehdään aikuiskoulutussovellutuksena kaupallisen alan jatkotutkinto, johon rakennetaan osioita ympäristöteknologiasta, verkostoitumisesta, kansainvälisyydestä, yrittäjyydestä, johtamisesta jne. Yhteiskuntaa ei voida putsata kaksikymppisten yhteiskunnaksi, vaan on toimittava olemassa olevan, työikäisen väen kanssa. Mielenkiintoista siis nähdä, mitä syntyy kokonaisuudesta, jossa ovat yliopistot, avoimet korkeakoulut, ammattikorkeakoulut ja avoimet ammattikorkeakoulut!

\section{AHTI}

Lisään listaasi vielä vapaan sivistystyön uudet työmuodot. Kun työpaikat eivät voi kouluttaa kaikessa, ihmiset joutuvat hankkimaan omana vapaa-aikanaan taitoja, joiden luontevin tarjoaja on vapaa sivistystyö. Hukkakoulutusta vähentävästä koordinoinnista tulee silloin tärkeä kysymys.

Erilaiset koulutusjärjestelmien diskriminointimekanismit on hyvin mielenkiintoinen kysymys. Uusi näkökulma on sitten se, mitä lopulta seuraa, kun on päässyt kultaisesta portista sisään. Nykyään voi tehdä yökaudet väitöskirjaa ja kokea lopulta saman kohtalon kuin peruskoulunkäynytkin, tosin toisenlaisin kokemuksin. Akateeminen ura ei enää takaa valoisaa tulevaisuutta. Tohtorin arvolla ei ole samaa arvostusta ja hohtoa kuin ennen, jolloin se oli itsestään selvästi jotain huippua. Kaikki tämä ravistelee myös yliopistoa, saattaa asettaa sen aseman kyseenalaiseksi. Kenties yliopiston on ryhdyttävä taistelemaan sen puolesta, että se on korkeamman tiedon tyyssija...

Reijo Raivola \& Eero Ropo (toim.) 1991. Jatkuva koulutus ja elinikäinen oppiminen. Tutkimusraportti A 49. Tampereen yliopisto, 393 sivua.

\section{CRISTINA}

Elinikäinen oppiminen on ollut valtiollisissakin puheissa jo pari vuosikymmentä. Myös Euroopan Unionissa käsite lifelong learning on tärkeä ja ajankohtainen.

Suomalaisissa yrityksissä ovat käynnistyneet keskustelut oppimisesta. Yritykset ovat oivaltaneet oppimisen tärkeäksi kilpailuetua tuottavaksi tekijäksi ja siksi panostukset erityisesti oppimiseen koulutuksen sijasta ovat lisääntymään päin. Siirtymisen murroskausi koulutusparadigmasta oppimisparadigmaan on vasta nyt alkanut huolimatta kauan jatkuneesta keskustelusta. Siksi Reijo Raivolan ja Eero Rovon toimittama tutkimusmateriaali on oikeastaan nyt ajankohtaisempi kuin tekoaikanaan, jolloin se oli vuorostaan ajastaan edellä.

Tutkimusraportin hyöty yrityksille on varmastikin suuri. Puutteena hyödyntämiselle on, kuten kaikissa tieteellisissä julkaisuissa, tiedon valtava määrä ja vaikea jäsentäminen.

Erityisesti raportista nousivat Raili Kaupin yleissivistynyttä ajattelua kohottava artikkeli sekä Kari Stachonin käytännönläheinen, mutta avarakatseinen artikkeli.

Jatkuvan koulutuksen periaatteen sovelluksia tutkailevassa artikkelissa todetaan, että jatkuvan koulutuksen periaate näyttää osittain koulutussuunnittelun juhlalliselta kulissilta. Tämä kuvannee hyvin nykyhetkeäkin niin yrityksissä kuin oppilaitoksissa. 
Vaikka itse olenkin suuresti ihastunut tutkimusraporttiin ja olen palannut siihen usein löytäen uusia näkökulmia ja käytännön ohjeistustakin omalle työlleni, niin luulen kuitenkin, että tässä muodossa tutkimusraportti ei varmastikaan ole antoisa yrityksissä oppimisen ja koulutuksen kautta työskenteleville henkilöille.

Mielestäni Tampereen yliopiston kannattaisi ehdottomasti jatkaa työskentelyä tutkimusraportin pohjalta kehittäen aineistosta sellaista oppimateriaalia, joka auttaisi yritysten johtoa ja kouluttajia oivaltamaan keskeisen viestin: koulutuksen ja oppimisen välisen suhteen ja vuorovaikutuksen.

\section{Maijaliisa Rauste- von Wright \& Johan von Wright 1994. Oppiminen ja koulutus. WSOY.}

Oppiminen ja koulutus on kirjoittajien oman empiirisen tutkimuksen pohjalle perustuva oppikirja. Kysymys on siis perustutkimuksesta, josta on tehty populaarimpi versio. Hyvinkin monimutkaiset tutkimusongelmat voidaan tuoda esille luettavassa ja helpohkossa muodossa, koska selkeästi kirjoitettu on myös selkeästi ajateltu, kuten teoksesta todettiin. Arvioryhmä pitikin Wrightien teosta oppikirjasarjansa parhaimmistoon lukeutuvana.

Teos sai osakseen myös yhdensuuntaisia moitteita: kirjasta löydettiin myös "silmänkääntöpedagogiikkaa", muiden ajatussuuntien leimaaminen koettiin ikävänä ja ajattelua katsottiin sävyttävän vissi vanhahtavuus.

ARJA

Monet ammattikorkeakoulujen opettajat ovat kokeneet tämän tutkimuksen omalle työlleen antoisaksi, heidän opettajanäkemystään terveellä tavalla ravistelevaksi. Oma perspektiivini tutkimukseen on toinen kuin ammattikorkeakoulun opettajan, enkä ole aivan yhtä viehättynyt. Moni asia, mitä Rantalaihon tutkimuksessa kehuin, on tässä tavallaan päinvastoin. Koen myös, että joiltakin osin se (lähinnä luku Opetussuunnitelma ja oppimiskäsitys) on jäänyt jo ajastaan jälkeen.

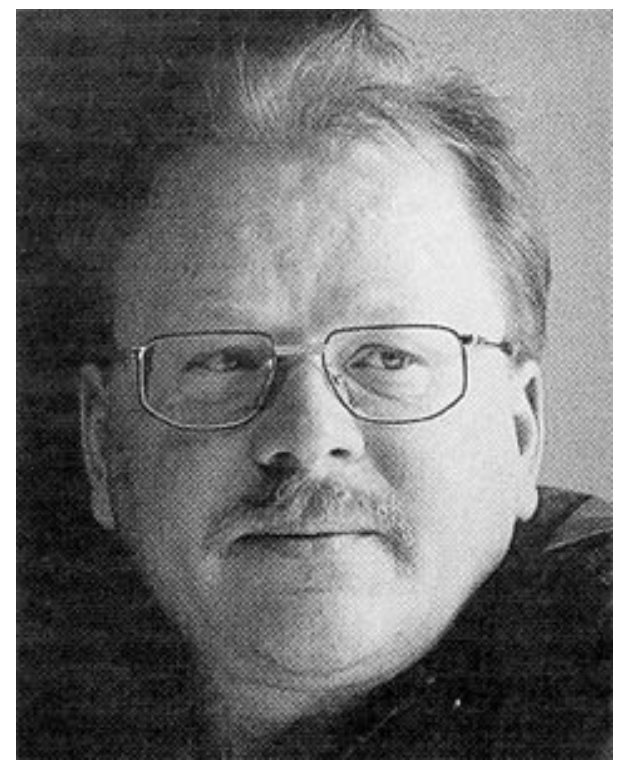

Matti Hermusta viehätti von Wrightien kirjassa se, että kirja tuulettaa käsityksiä ja asettaa myös nykyisiä käytäntöjä kyseenalaiseksi.

\section{MATTI}

Ymmärrän näkökulmasi. On pakko myötää, että tämä tutkimus ei ole raikas kuten Rantalaihon, ehkä osaamisen osalta jopa tunkkainen. Toisaalta tämäkin tuulettaa ja asettaa nykyiset käytännöt kyseenalaisiksi. Minua myös viehättää se, että tutkimus osoittaa selvästi tiettyihin asioihin rajoituksia ja vie eteenpäin.

Mielestäni tämä on varteenotettava ja mielenkiintoinen, myös uutta tuova teos, vaikka jotkut asiat toistuvat turhan monessa kohtaa. Kokeneen ammatti-ihmisen ajattelua se taatusti rassaa sitä rikastuttaen. Tutkimus ajaa kuitenkin liiaksi omaa asiaa ja oman ajattelun puolta ja on jollain tavalla myös konservatiivinen.

ARJA

Esimerkkinä tuosta on vaikkapa debattitekniikka. Ei se ole kirjoittajien keksimä tekniikka. Mitä muuta Sokrateen opetusmenetelmä oli, ellei juuri väittelyä? 


\section{AHTI}

Vapaassa sivistystyössä olen kokenut kaiken avoimena. Nyt sen sijaan törmää tavan takaa erilaisiin henkisen työn copy righteihin, missä joku katsoo kehittäneensä jonkun metodin ja markkinoi sitä omana "tuotteenaan". Näinhän esimerkiksi NLP:llä tehdään bisnestä.

Kunnioitan molempia von Wrightejä heidän aikaisemmista tutkimuksistaan kognitiivisen oppimisen ja kognitiivisen psykologian alueella. Olen saanut niistä omaan työhöni paljon virikkeitä. Nyt en kuitenkaan voinut välttyä tietystä pinnallisuuden vaikutelmasta, mikä syntyi eräiden muotitermien liimaamisesta mukaan. Ihmissuhdetyö kirjan lopussa on mielenkiintoinen, koska sitä voi ajatella aika laajasti ohi ja yli terapian.

Pekka Ruohotie 1993. Ammatillinen kasvu työelämässä. Tampereen yliopiston Hämeenlinnan opettajankoulutuslaitos. Ammattikasvatussarja 8.362 sivua.

Pekka Ruohotien Ammatillinen kasvu työelämässä kiinnosti monia ja oli Arjan suosikkilistalla nimenomaan käyttöarvonsa vuoksi. Mikko luonnehti kirjaa ammattikorkeakoulun opettajan perusteokseksi, jota ei sovi sivuuttaa. Itselleen hän koki asiat siinä määrin tutuiksi, ettei teos enää voinut sytyttää hänessä henkilökohtaisesti sielunpaloa. Kirja koettiinkin ammattilaisen tekemäksi, hyödylliseksi koosteeksi, missä on keskeisiä teorioita ja ammatillisen koulutuksen ydinsisältöjä. "Tärkeä tsekkauskirja oman työhuoneen hyllyssä, vaikken henkilökohtaisesti siitä syty", kuului Matin kommentti.

Teos sai rajuja moitteita tyylistään ja ulkoasustaan. Esimerkiksi Lukijalle-lukuna painoon oli päässyt tyystin väärä teksti ja joku aukeama oli kirjassa kahteen kertaan. Ulkoasun, sisällöllisen viimeistelemättömyyden ja oikoluvun heikkouksien katsottiin nakertavan tarpeettomasti kirjan uskottavuutta. Pidettiin myös valitettavana, ettei näinkään laajaan teokseen ole mahtunut mukaan kaikki oleellinen Suomessa aiheesta kirjoitettu ja tutkittu, mikä todella olisi tehnyt teoksesta oivallisen käsikirjan.

\section{AHTI}

Minusta se on ideakirjana hyvä, ja aika miellyttävä lukeakin, vaikka kirjan eräät dramaattiset virheet panevat epäilemään, onko kirja tehty huolellisesti ja loppuun harkiten.

Minua lämmitti se, mitä johtamismalleista on kirjoitettu. Se johti ajatukseen, että tietynlainen johtamisjärjestelmä johtaa vääjäämättä ongelmiin Koron tutkimuksessa puhutussa itseohjautuvassa oppimisessa.

Kirja herättää opettajan ammatillisesta kehittymisestä ajatuksia Kari Rantalaihon työn suuntaan. Luvussa Koulutuksen ja kehittymisen arviointi tuodaan rationalistisen paradigman rinnalle naturalistinen paradigma, johon liittyy sanattoman tiedon käyttö, ja asioita viedään myös arkeen.

Pekka Ruohotieltä ilmestyy juuri uusi teos nimeltä Osaaminen ja ammatillinen kasvu. Ruohotie on myös yksi käsikirjan International Handbook for Educational Leadership and Administration (Kluwer Publisher 1996) kirjoittajista. Artikkelin nimi on Professional Growth and Development. Kirja julkistetaan huhtikuussa New Yorkissa.

\section{Tiivistelmistä olisi hyötyä}

Luku-urakan jälkeen arviointiryhmän jäsenet ilmaisivat ilonsa ja tyytyväisyytensä. Tehtävä koettiin itselle tärkeäksi oppimisprosessiksi. Käytännön aikuiskouluttaja tuskin ryhtyy omatoimisesti arvioimaan alansa tutkimuksia samanlaisella systemaattisuudella, vaan oman työn ohessa lukee mitä lukee. Ryhmän jäsenet kokivat saaneensa hyvän kokonaiskuvan suomalaisesta aikuiskasvatustutkimuksesta, jollainen olisi tarpeellista saada aina aika aloin.

Aikuiskasvatus-tehden toivottiin julkaisevan kirja-arviointien ja esittelyjen lisäksi mahdollisimman tuoreeltaan hyvin lyhyet tiivistelmät alan kirjallisuudesta ja tutkimuksesta, mistä kiireinen lukija saisi nopean mielikuvan, mitä kaikkea alalla tapahtuu ja mikä voisi olla itseä kiinnostavaa. Perusteellisemman esittelyn lehti voisi tehdä myöhemmin, omista toimituspoliittisista intresseistään käsin. 
Raportin koonnut: ANNELI KAJANTO

Kuvat: KALEVI KESKI-KORHONEN

Aikuiskasvatus kiittää lämpimästi opetushallitusta arviointiryhmän työhön osoitetusta tuesta. 